ISSN 1392-3196 / e-ISSN 2335-8947

Zemdirbyste-Agriculture, vol. 107, No. 4 (2020), p. 337-344

DOI $10.13080 /$ z-a.2020.107.043

\title{
Effects of foliar application of solutions of ascorbic acid, glycine betaine, salicylic acid on the yield and seed germination of soybean in South Eastern Europe conditions
}

\author{
Zlatica MILADINOV ${ }^{1}$, Svetlana BALESEVIC TUBIC ${ }^{1}$, Jovan CRNOBARAC ${ }^{2}$, \\ Jegor MILADINOVIC ${ }^{1}$, Petar CANAK ${ }^{1}$, Vojin DJUKIC ${ }^{1}$, Kristina PETROVIC ${ }^{1}$ \\ ${ }^{1}$ Institute of Field and Vegetable Crops \\ Maksima Gorkog 30, 21000 Novi Sad, Serbia \\ E-mail: zlatica.miladinov@ifvens.ns.ac.rs \\ ${ }^{2}$ University of Novi Sad \\ Dositeja Obradovića 8, 21000 Novi Sad, Serbia
}

\begin{abstract}
The aim of the research was to test the effect of foliar-applied solutions of ascorbic acid (AsA), glycine betaine (GB), salicylic acid (SA) and water as a second control on the yield and seed germination of the soybean (Glycine hispida (Moench) Maxim.) cultivar 'Sava' as well as their influence on the content of N, P, K and Ca in soybean seeds, and to estimate the intensity of lipid peroxidation and free proline content in soybean seedlings. The plants were treated with the solutions twice. The $1^{\text {st }}$ spray treatment was done at growth stage 6: flowering (main shoot), when first flowers opened (sporadically in population), and the $2^{\text {nd }}$ spray treatment was done at growth stage 7 : development of fruits and seeds, when the first pod had reached final length of 15-20 mm.

Foliar application of the solutions had a significant impact on seed yield and seed germination in both years of the experiment. In a favourable year 2016, treatments with ascorbic acid, glycine betaine and salicylic acid solution significantly increased seed yield by $6.21-9.67 \%$. However, in an unfavourable year 2017 , the effect was significantly greater with the application of water (yield increase $6.48 \%$ ), while the application of glycine betaine solution even reduced the seed yield. In a favourable year 2016, treatments with ascorbic acid and salicylic acid solution significantly increased seed germination by $7 \%$ and $8 \%$, respectively. In an unfavourable year 2017 , also only ascorbic acid and salicylic acid significantly increased seed germination by $11 \%$ and $9 \%$, respectively. However, when using cold test, when the seed was exposed to a low temperature of $10^{\circ} \mathrm{C}$ for 7 days and then placed under optimal seed germination conditions for 4 days, ascorbic acid and glycine betaine solution reduced seed germination in both experimental years.

Therefore, further research is needed on the methods designed to increase seed germination of soybean, both in favourable and adverse conditions in Serbia.
\end{abstract}

Key words: ascorbic acid, germination, glycine betaine, salicylic acid, yield.

\section{Introduction}

In addition to Italy and France, Serbia is among the largest soybean producers in Europe. Soybean areas have been in an upward trend over the past 10-year period, ranging between 144.000 and 202.000 ha. In 2018, an area of over 196.000 ha was recorded. Record area under soybean was in 2017. Average soybean yields in the last ten years are at $2.7 \mathrm{tha}^{-1}$, with a minimum of $1.7 \mathrm{t} \mathrm{ha}^{-1}$ in 2012 and a maximum of $3.5 \mathrm{t} \mathrm{ha}^{-1}$ in 2014, which ranks Serbia among the countries with the highest average yield in Europe (www.stat.gov.rs, 2020). Northern province of Vojvodina is very suitable for soybean production because of its favourable climate and soil characteristics. However, limiting factors for soybean development are amount and distribution of rainfall (Mandić et al., 2017). A decrease in seed quality in addition to lower seed yields also causes water deficit at critical (from $\mathrm{BBCH}$ 60600 to 70700 ) stages of soybean development, in the agrometeorological conditions of Serbia during June, July and August (Vujakovic et al., 2011).

Therefore, different methods are used to increase the germination of soybean seeds, and these methods are applied to stored seeds (Miladinov et al., 2015; Đukić et al., 2017). However, because of the morphological structure, soybean seeds are very sensitive, so additional treatments after seed processing decrease seed germination (Kuźniar et al., 2016).

Please use the following format when citing the article:

Miladinov Z., Balesevic Tubic S., Crnobarac J., Miladinovic J., Canak P., Djukic V., Petrovic K. 2020. Effects of foliar application of solutions of ascorbic acid, glycine betaine, salicylic acid on the yield and seed germination of soybean in South Eastern Europe conditions. Zemdirbyste-Agriculture, 107 (4): 337-344. DOI 10.13080/z-a.2020.107.043 
Foliar spraying of plants with ascorbic acid solution during reproductive stage may be an effective strategy to overcome the adverse effects of environmental constraints (Çavuşoğlu, Ergin, 2015). Çavuşoğlu and Bilir (2015) found that the use of ascorbic acid can have a positive effect on the plant due to its role in many physiological processes, including seed germination, flowering, membrane permeability, seedling growth, intake of ions, respiration, photosynthesis, senescence, protein and nucleic acid content, and enzyme activity, e.g., peroxidase (POD) and superoxide dismutase (SOD).

The use of glycine and salicylic acid can also have a positive effect on the plant. Glycine betaine has wide-spectrum functions, including scavenging of reactive oxygen species (ROS), balancing of cell redox status, acting as osmoprotectants, stabilization of cytosolic acidity $(\mathrm{pH})$, proteins, enzymes and membranes as well as acting as a potential source of carbon (C) and nitrogen $(\mathrm{N})$ for plants both during stress events, and the subsequent recovery episodes (Kumar, Khare, 2015).

Salicylic acid is a plant growth regulator with various roles in plant metabolism. One of the most prominent roles of salicylic acid is in stress tolerance of plants, where it can act as a signalling molecule that induces resistance (Jayakannan et al., 2015). Teixeira et al. (2017) found that foliar application of amino acids, glutamate, phenylalanine, cysteine and glycine significantly increased soybean resistance and yield. Foliar application of ascorbic acid, salicylic acid, pyridoxine, tocopherol and their combinations significantly increased the yield and seed germination (Naneswara, 2016). Use of salicylic acid showed positive effect on seed yield, seed health, seed germination and seed vigour during storage. Also, application of $\alpha$-tocopherol and salicylic acid improved the storage or keeping quality of soybean seeds (Kuchlan et al., 2017). However, besides the positive effect on plants, the foliar application of solution in certain conditions can also have an inhibitory effect (Çavuşoğlu, Ergin, 2015).

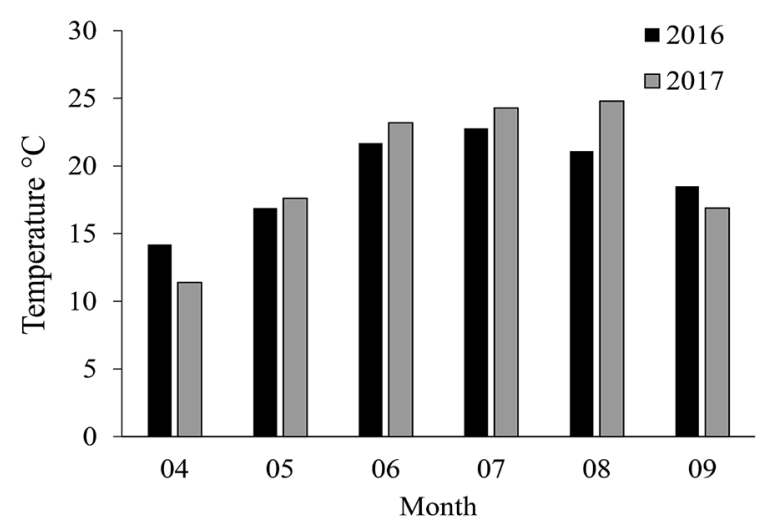

Figure 1. Monthly temperature of the vegetation season in 2016 and 2017

Due to very high temperatures from May to August and deficiency of rainfall in the period from June to the end of August, in 2017 there occurred a forced maturation of the plants and a shortening of the vegetation period by 10 days, which is one of the factors that influenced the decrease in soybean seed yield and seed germination (Table 1).

Soil winter precipitation reserves were about $20 \mathrm{~mm}$ higher in 2016. During the vegetation period in
Therefore, the aim of the current study was to examine the effect of foliar-applied solutions of ascorbic acid (AsA), glycine betaine (GB), salicylic acid (SA) and water as a second control on the yield and seed germination of the soybean (Glycine hispida (Moench) Maxim.) cultivar 'Sava' as well as the their influence on the content of N, P, K and Ca in soybean seeds and to estimate the intensity of lipid peroxidation and free proline content in soybean seedlings as influenced by the climatic conditions.

\section{Materials and methods}

Field trials were conducted with a soybean (Glycine hispida (Moench) Maxim.) cultivar 'Sava' developed during two growing seasons, 2016 and 2017, on a chernozem (WRB, 2014), at Rimski Šančevi experimental field $\left(45^{\circ} 20^{\prime} \mathrm{N} 19^{\circ} 51^{\prime} \mathrm{E}\right)$, in the Institute of Field and Vegetable Crops in Novi Sad, Serbia.

Weather conditions. An analysis of the amount of precipitation during the vegetation period in 2016 and 2017 showed that about $54.71 \%$ more rain fell in 2016. Not only the amount of precipitation, but also its distribution significantly differed between the two experimental years, and the growing season of 2016 was significantly more favourable compared to the previous season. In 2016, the least rain fell in September $(33.2 \mathrm{~mm})$ (the amount of precipitation was measured until 27 September, i.e. until the soybean harvest), and the most in July (143.2 mm). In 2017, the least rain fell in July $(12 \mathrm{~mm})$, and the most in August $(82.5 \mathrm{~mm})$. Apart from precipitation during the vegetation season in 2016 and 2017, there were also differences in the air temperature. In 2016, the average monthly temperature of July was $22.8^{\circ} \mathrm{C}$. In 2017 , in July, when there was the least precipitation, the average monthly temperature was $24.3^{\circ} \mathrm{C}$, which is $1.5^{\circ} \mathrm{C}$ higher compared to the previous year (www.hidmet.gov.rs, 2020) (Figs 1 and 2).

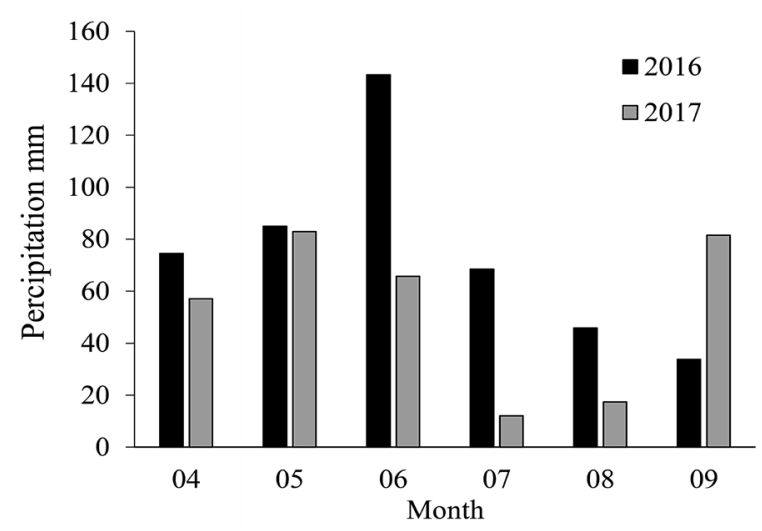

Figure 2. Monthly precipitation of the vegetation season in 2016 and 2017

2016 there was $231.7 \mathrm{~mm}$ more precipitation, or $54.71 \%$ more than in 2017. An analysis of the water needs of plants and the amount of precipitation by individual years revealed that in 2016, the needs were $440 \mathrm{~mm}$ and the available water amount was $410 \mathrm{~mm}$. The water needs in 2017 were higher due to high temperatures and amounted to $475 \mathrm{~mm}$, while only $200 \mathrm{~mm}$ of water was available to the plants. The water deficit in 2016 was 30 $\mathrm{mm}$ and in $2017-275 \mathrm{~mm}$ (www.hidmet.gov.rs). The 
Table 1. Main dates of soybean vegetation period in 2016 and 2017

\begin{tabular}{|c|c|c|c|c|c|c|c|c|}
\hline \multirow[b]{2}{*}{ Year } & \multicolumn{7}{|c|}{ Date of } & \multirow{2}{*}{$\begin{array}{c}\text { Length of } \\
\text { growing season, } \\
\text { days }\end{array}$} \\
\hline & sowing & sprouting & $\begin{array}{l}\mathrm{BBCH} \\
60600 \\
\end{array}$ & $\begin{array}{l}\mathrm{BBCH} \\
70700 \\
\end{array}$ & maturation & harvest & $\begin{array}{l}\text { germination } \\
\text { after harvest }\end{array}$ & \\
\hline 2016 & 10 April & 1 May & 22 June & 30 June & 6 September & 27 September & 8 October & 128 \\
\hline 2017 & 20 April & 5 May & 18 June & 25 June & 1 September & 13 September & 24 September & 118 \\
\hline
\end{tabular}

Note. BBCH 60600 - first flowers opened (sporadically in population); BBCH 70700 - first pod have reached final length (15$20 \mathrm{~mm}$ ); seeds filling the cavity of the majority of pods (Munger et al., 1997).

water deficit in 2016 occurred on 18.08 , that is 19 days before maturation of soybean, while in 2017 soybean was exposed 65 days to deficit of precipitation (Table 2).

The trial was set up as a randomized block design with four replications under the conditions of dry farming. Plot size was $10 \mathrm{~m}^{2}$. Inter-row spacing of $50 \mathrm{~cm}$ and intra-row spacing of $4.5 \mathrm{~cm}$ was applied. Each year the plots with soybean plants were rotated with maize (Zea mays L.). Nitrogen $(\mathrm{N})$ fertilizer was applied at two rates: $30 \mathrm{~kg} \mathrm{ha}^{-1}$ (NPK 15:15:15, $200 \mathrm{~kg}$ $\mathrm{ha}^{-1}$ ) before sowing and $34 \mathrm{~kg} \mathrm{ha}^{-1}$ (ammonium nitrate, $34 \% \mathrm{~N}$ ) before seed bed preparation in early April. There were no significant disease and insect attacks during the vegetation period. Soybean seeds of the cultivar 'Sava' were sown in the first ten days of April. Plants were treated twice with ascorbic acid, glycine betaine and salicylic acid solution. The $1^{\text {st }}$ spray treatment was done at growth stage 6 (BBCH 60 600): flowering (main shoot), when first flowers opened (sporadically in population), and the $2^{\text {nd }}$ spray treatment was done at growth stage $7(\mathrm{BBCH}$ 70 700): development of fruits and seeds, when first pod reached final length $(15-20 \mathrm{~mm})$. The spray applications were performed with an atomizer sprayer (Villager VBS 16 LI-Ion, Serbia) with $0.6-0.7 \mathrm{~mm}$ nozzles. The solution was applied at a pressure of $1.5 \mathrm{MPa}$. The following spray application treatments were used: 1) control - without foliar spray, 2) water as a second control, 3) ascorbic acid (AsA) $400 \mathrm{mg} \mathrm{l}^{-1}$, 4) glycine betaine (GB) $3 \mathrm{~kg} \mathrm{ha}^{-1}$, and 5) salicylic acid (SA) 50 ppm solutions.

Table 2. Potential and actual evapotranspiration (mm) during soybean vegetation in 2016 and 2017

\begin{tabular}{|c|c|c|c|c|c|c|}
\hline Year & $\begin{array}{c}\text { Soil moisture } \\
\text { content at sowing }\end{array}$ & Precipitation & $\begin{array}{c}\text { Potential } \\
\text { evapotranspiration }\end{array}$ & $\begin{array}{l}\text { Evapo- } \\
\text { transpiration }\end{array}$ & $\begin{array}{c}\text { Precipitation } \\
\text { deficit }\end{array}$ & $\begin{array}{c}\text { Drought start } \\
\text { date }\end{array}$ \\
\hline 2016 & 51.28 & 423.5 & 440 & 410 & -30 & 18 August \\
\hline 2017 & 29.63 & 191.8 & 475 & 200 & -275 & 25 June \\
\hline
\end{tabular}

The grain was harvested with a small plot combine harvester (Wintersteiger, Austria). After basic plot harvesting, grain weight and moisture were measured, and the yield was calculated in $\mathrm{kg} \mathrm{ha}^{-1}$ and adjusted to a grain moisture content of $14 \%$.

Seed germination was performed under laboratory conditions immediately after harvest using the standard laboratory method and cold test in the Laboratory for Seed Testing in Novi Sad (Hampton, TeKrony, 1995; ISTA, 2008). The standard laboratory test was performed for $4 \times 100$ seeds using sand. The incubation period was 8 days at $25^{\circ} \mathrm{C}$ and $95 \%$ relative humidity (ISTA, 2008). In a cold test, the seed was exposed to a low temperature of $10^{\circ} \mathrm{C}$ for 7 days and then placed under optimal germination conditions for 4 days; then seed germination was evaluated. A 2:1 mixture of soil and sand was used as the substrate (Hampton, TeKrony, 1995).

After 8 days, 4 replicates $\times 10$ average seedlings were taken from each treatment and used to determine the intensity of lipid peroxidation and free proline content. Intensity of lipid peroxidation was carried out using the Placer et al. (1966) method. Extraction of malondialdehyde (MDA) from soybean fresh seedlings was done by using solution of thiobarbituric acid (TBA), trichloroacetic acid $\left(\mathrm{CCl}_{3} \mathrm{COOH}\right)$ and perchloric acid $\left(\mathrm{HClO}_{4}\right)$, and the concentration was determined spectrophotometrically at $532 \mathrm{~nm}$. Soybean fresh seedlings $(0.5 \mathrm{~g})$ were homogenized in a mortar with $4.5 \mathrm{ml}$ extraction solution and incubated in a water bath at $90^{\circ} \mathrm{C}$ temperature for $20 \mathrm{~min}$. After incubation, the solution was cooled to stop the reaction and centrifuged for $10 \mathrm{~min}$ at $5500 \mathrm{r} \mathrm{min}^{-1}$. MDA acumulation, i.e. intensity of lipid peroxidation, was expressed as mmol g-1 FW (fresh weight). Free proline content was determined by the Bates et al. (1973) method. Soybean fresh seedlings $(1 \mathrm{~g})$ were extracted with $3 \%$ sulphosalicylic acid. The extracts $(2 \mathrm{ml})$ were kept for $1 \mathrm{~h}$ in boiling water by adding $2 \mathrm{ml}$ ninhydrin and $2 \mathrm{ml}$ glacial acetic acid, after which cold toluene $(4 \mathrm{ml})$ was added. Free proline content was measured by a spectrophotometer (PerkinElmer, UK) at $520 \mathrm{~nm}$ and calculated as $\mu \mathrm{mol} \times \mathrm{g}^{-1} \mathrm{FW}$ against standard proline.

Concentration of total $\mathrm{N}$ was determinated in soybean dry seedlings according to the Kjeldahl method (Bremner, 1996). Concentrations of phosphorus (P), potassium $(\mathrm{K})$ and calcium $(\mathrm{Ca})$ were determinated in soybean dry seedlings. Contents of mineral elements were determined with inductively coupled plasma-optical emission spectrometry (ICP-OES) (PerkinElmer, USA). The digestive content of the closed microwave samples was applied under high pressure with gradual heat to $180^{\circ} \mathrm{C}$ temperature by Milestone Ethos 1 (Milestone, Italy). Sample digestion was done with concentrated $\mathrm{HNO}_{3}$ and $\mathrm{H}_{2} \mathrm{O}_{2}\left(5 \mathrm{HNO}_{3}: 1 \mathrm{H}_{2} \mathrm{O}_{2}\right)$. The ratio of the sample and solution was 1:24 (Plank, 1992).

The data were analysed using one-way analysis of variance (ANOVA). The mean values from treatments were compared using Tukey's HSD (honestly significant difference) test. The AMMI model was used to analyse the interaction. AMMI analysis of variance and AMMI1 biplot were done using software GenStat (VSN International, UK). 


\section{Results and discussion}

Soybean seed yield. The foliar-applied solutions had a significant impact on soybean yield in both years of the experiment. However, the influence of the solutions was more pronounced, when the plants were better supplied with water (Table 3).
In 2016, ascorbic acid, glycine betaine and salicylic acid solutions seed yield increased by $6.21-$ $9.67 \%$. The best effect was achieved by using salicylic acid, which agrees with the results of Hasanah et al. (2017). The beneficial impact of salicylic acid on plants can be attributed to its role in promoting nutrient uptake and transport (Shao et al., 2018), and the result is an

Table 3. Influence of spray with water, ascorbic acid, glycine betaine and salicylic acid on soybean seed yield and seed germination immediately after harvest

\begin{tabular}{|c|c|c|c|c|c|c|}
\hline \multirow[t]{2}{*}{ Treatment } & \multicolumn{2}{|c|}{$\begin{array}{l}\text { Yield } \\
\mathrm{kg} \mathrm{ha}^{-1}\end{array}$} & \multicolumn{2}{|c|}{$\begin{array}{c}\text { Germination } \% \\
\text { at } 25^{\circ} \mathrm{C}\end{array}$} & \multicolumn{2}{|c|}{$\begin{array}{c}\text { Germination } \% \\
\text { at } 10^{\circ} \mathrm{C}\end{array}$} \\
\hline & 2016 & 2017 & 2016 & 2017 & 2016 & 2017 \\
\hline Control & $4075 \mathrm{~d}$ & $1343 \mathrm{~b}$ & $87 \mathrm{~b}$ & $74 b$ & $86 \mathrm{ab}$ & $72 \mathrm{~b}$ \\
\hline Water & $4160 \mathrm{c}$ & $1430 \mathrm{a}$ & $88 \mathrm{~b}$ & $76 \mathrm{~b}$ & 88 a & $75 \mathrm{a}$ \\
\hline Ascorbic acid & $4328 \mathrm{~b}$ & $1419 \mathrm{a}$ & $94 \mathrm{a}$ & $85 \mathrm{a}$ & $81 \mathrm{~cd}$ & $69 \mathrm{c}$ \\
\hline Glycine betaine & $4507 \mathrm{a}$ & $1319 b$ & $90 \mathrm{~b}$ & $76 \mathrm{~b}$ & $79 \mathrm{~d}$ & $65 \mathrm{~d}$ \\
\hline Salicylic acid & $4512 \mathrm{a}$ & $1406 \mathrm{a}$ & $95 \mathrm{a}$ & $83 \mathrm{a}$ & $83 \mathrm{bc}$ & $71 \mathrm{bc}$ \\
\hline
\end{tabular}

Note. Different letters in each column represent significant difference at $p \leq 0.05$ according to Tukey's HSD test.

increase in productivity. Exogenous application of plant growth regulator Cycocel (a.i. chlormequat chloride) and salicylic acid through foliar spray is known to increase seed yield of soybean by modulating the physiological pathways within the plants (Tarun et al., 2016). Salicylic acid is an orthohydroxybenzoic acid and a secondary metabolite acting as an analogue of growth regulating substances existing in minor $\left(1 \mu \mathrm{g} \mathrm{g}^{-1}\right)$ concentrations in plants such as soybean having diverse roles in biotic and abiotic stresses (Aydin, Nalbantoğlu, 2011). Besides the positive impact on yield, the application of a solutions can have a negative effect. In 2017, when the water deficit was $245 \mathrm{~mm}$ higher than in 2016 and the average monthly air temperatures were $1.5-3.7^{\circ} \mathrm{C}$ higher, ascorbic and salicylic acids soybean yield increased by $5.36 \%$ and $4.48 \%$, respectively, while glycine betaine had an inhibitory effect by reducing the yield by $1.82 \%$.

Seed germinaton. Foliar spray application of the tested solutions had a significant impact on seed germination in both years of the experiment. However, the effect of the solutions was greater, when the plants were poorly provided with water during the growing season. In 2016, treatment with ascorbic acid, glycine betaine and salicylic acid solution lead to an 3-8\% increase in seed germination (Table 3 ). A significant increase in seed germination was achieved by the application of salicylic and ascorbic acids $-7.75 \%$ and $6.50 \%$, respectively. In 2017 , the use of a ascorbic acid, glycine betaine and salicylic acid solutions seed germination increased by $2.00-11.00 \%$. Significant increase in seed germination was achieved by application of salicylic and ascorbic acids $-11 \%$ and $9 \%$, respectively. The beneficial effect of salicylic acid on germination on soybean seeds was also determined by Naneswara (2016), Kuchlan et al. (2017) and Dalcin et al. (2019). Kuchlan et al. (2017) suggest that the improvement of seed germination is due to less contamination of soybean seeds by pathogenic organisms due to the effect of salicylic acid and due to the decreased intensity of lipid peroxidation.

In adverse conditions, a greater (but not significant) effect was achieved using ascorbic acid. Miladinov et al. (2020) suggest that the beneficial effect of ascorbic acid on germination of soybean seeds is due to a decrease in lipid peroxidation intensity and increased free proline accumulation. Also, the beneficial effect of ascorbic acid can be attributed to its positive effect in the process of biosynthesis of gibberellin (Shu et al., 2013) and cytokinin (Huang et al., 2017) - hormones that have a stimulating effect on the seed germination process. Using the cold test, the seeds treated with the active substances will be significantly more sensitive to low temperatures. Seed germination was similarly reduced in both years of the experiment. Many studies have shown that the effect of exogenous application of different solutions depends on stage of development of different plant species including soybean, method of application and concentration (Horváth et al., 2015). Studies show that the effect of ascorbic acid, glycine betaine and salicylic acid solutions depends on the weather conditions of the growing season but also on the temperature that the seed has been exposed to in the germination process.

Lipid peroxidation intensity and free proline content in soybean seedlings. The results showed that weather conditions had a significant effect on the intensity of lipid peroxidation, and that the use of ascorbic acid, glycine betaine and salicylic acid solutions had the potential to reduce its detrimental effect on germination of soybean seeds (Table 4).

Table 4. Influence of spray with water, ascorbic acid, glycine betaine and salicylic acid on lipid peroxidation and free proline content in soybean seedlings

\begin{tabular}{lcccc}
\hline \multirow{2}{*}{ Treatment } & \multicolumn{2}{c}{$\begin{array}{c}\text { Lipid peroxidation } \\
\mathrm{mmol} \times \mathrm{g}^{-1} \mathrm{FW}\end{array}$} & \multicolumn{2}{c}{$\begin{array}{c}\text { Free proline } \\
\mu \mathrm{mol} \times \mathrm{g}^{-1} \mathrm{FW}\end{array}$} \\
\cline { 2 - 5 } & 2016 & 2017 & 2016 & 2017 \\
\hline Control & $36.33 \mathrm{a}$ & $65.05 \mathrm{a}$ & $2.90 \mathrm{a}$ & $3.90 \mathrm{a}$ \\
Water & $35.10 \mathrm{a}$ & $63.70 \mathrm{a}$ & $2.87 \mathrm{a}$ & $3.60 \mathrm{a}$ \\
Ascorbic acid & $18.20 \mathrm{~b}$ & $47.65 \mathrm{c}$ & $3.12 \mathrm{a}$ & $2.11 \mathrm{~b}$ \\
Glycine betaine & $20.20 \mathrm{~b}$ & $55.60 \mathrm{~b}$ & $2.98 \mathrm{a}$ & $2.33 \mathrm{~b}$ \\
Salicylic acid & $34.20 \mathrm{a}$ & $45.20 \mathrm{c}$ & $2.93 \mathrm{a}$ & $1.20 \mathrm{c}$ \\
\hline
\end{tabular}

Note. Different letters in each column represent significant difference at $p \leq 0.05$ according to Tukey's HSD test; FW fresh weight.

Cai et al. (2011) point out that the decrease in seed germination is due to an increase in the intensity of lipid peroxidation, i.e. an increased accumulation of MDA, whose content is an indicator of cell membrane damage and is associated with uncontrolled reactive 
oxygen species (ROS) accumulation. When found in larger quantities, ROS has the potential to oxidate cellular proteins, lipids and DNA, resulting in a change in cell structure and function, damage and death (Valko et al., 2004).

The use of ascorbic acid resulted in a significant decrease in the intensity of lipid peroxidation in soybean seedlings, regardless of the weather conditions. In 2016, the intensity lipid peroxidation decreased by $49.90 \%$, while in 2017 the decrease was $26.75 \%$. Glycine betaine had a lower effect, while salicylic acid only in 2017 the lipid peroxidation intensity reduced by $30.51 \%$. The use of water had no statistical significance. The positive impact of ascorbic acid on the decrease in lipid peroxidation intensity and, consequently, on the increase in seed germination can be attributed to its inhibitory role in MDA accumulation (Sadak, 2015).

Also, glycine is involved in the production of glycosylates, compounds that can reduce water content in plants, leading to a decrease in lipid peroxidation (Alhasawi et al., 2015). The effect of the solution on the free proline content is more effective at lower plant water supply. In 2017, the application of ascorbic acid, glycine betaine and salicylic acid significantly decreased the content free proline in seeds (Table 4). The application of salicylic acid the free proline content of seeds reduced by more than three times that of untreated seeds, while the use of water it reduced by $7.69 \%$.

$N, P, K$ and $C a$ content in soybean seedlings. The application of ascorbic acid, glycine betaine and salicylic acid solutions had no effect on the $\mathrm{N}$ content of soybean seeds in 2016. However, in 2017, its content was reduced by $4.04 \%$ by the use of ascorbic acid solution, which can be considered one of the factors that led to a decrease in seed germination given its importance in metabolic processes (Table 5).

Two of the most important $\mathrm{N}$ compounds, proteins and amino acids, are essential during seed germination and seedlings growth. During seed germination, the storage proteins are mobilised into soluble peptides and free amino acids, and then these compounds are translocated to the embryonic axis to provide energy (Tan-Wilson, Wilson, 2012). In seedlings, amino acids are a source of carbon for precursors of key metabolites involved in the tricarboxylic acid cycle and sugar synthesis (Gallardo et al., 2001).

Table 5. Influence of spray with water, ascorbic acid, glycine betaine and salicylic acid on nitrogen (N), phosphorus $(\mathrm{P})$, potassium $(\mathrm{K})$ and calcium $(\mathrm{Ca})$ content $(\%)$ in soybean seedlings

\begin{tabular}{lcccccccc}
\hline \multirow{2}{*}{ Treatment } & \multicolumn{3}{c}{$\mathrm{N}$} & \multicolumn{2}{c}{$\mathrm{P}$} & \multicolumn{2}{c}{$\mathrm{Ca}$} \\
\cline { 2 - 7 } & 2016 & 2017 & 2016 & 2017 & 2016 & 2017 & 2016 \\
\hline Control & $5.260 \mathrm{a}$ & $5.693 \mathrm{ab}$ & $0.561 \mathrm{a}$ & $0.542 \mathrm{a}$ & $1.456 \mathrm{a}$ & $1.410 \mathrm{a}$ & $0.308 \mathrm{a}$ & $0.422 \mathrm{a}$ \\
Water & $5.232 \mathrm{a}$ & $5.461 \mathrm{c}$ & $0.559 \mathrm{ab}$ & $0.505 \mathrm{c}$ & $1.421 \mathrm{~b}$ & $1.371 \mathrm{~b}$ & $0.318 \mathrm{a}$ & $0.401 \mathrm{bc}$ \\
Ascorbic acid & $5.295 \mathrm{a}$ & $5.558 \mathrm{bc}$ & $0.554 \mathrm{ab}$ & $0.519 \mathrm{bc}$ & $1.442 \mathrm{ab}$ & $1.391 \mathrm{ab}$ & $0.304 \mathrm{a}$ & $0.418 \mathrm{ab}$ \\
Glycine betaine & $5.270 \mathrm{a}$ & $5.720 \mathrm{ab}$ & $0.552 \mathrm{ab}$ & $0.547 \mathrm{a}$ & $1.395 \mathrm{c}$ & $1.382 \mathrm{ab}$ & $0.310 \mathrm{a}$ & $0.398 \mathrm{c}$ \\
Salicylic acid & $5.170 \mathrm{a}$ & $5.741 \mathrm{a}$ & $0.548 \mathrm{~b}$ & $0.525 \mathrm{~b}$ & $1.427 \mathrm{~b}$ & $1.389 \mathrm{ab}$ & $0.303 \mathrm{a}$ & $0.427 \mathrm{a}$ \\
\hline
\end{tabular}

Note. Different letters in each column represent significant difference at $p \leq 0.05$ according to Tukey's HSD test.

In both experimental years, regardless of the weather conditions, all solutions reduced $\mathrm{P}$ content in soybean seedlings. Only the application of glycine betaine in 2017 had no significant impact. However, in this treatment it had the weakest effect on germination of soybean seeds under optimal temperature conditions, i.e. germination was significantly reduced at lower temperature.

Due to the use of ascorbic acid, glycine betaine and salicylic acid solutions and water, the content of $\mathrm{K}$ in soybean seeds decreased, regardless of the weather conditions. The smallest decrease occurred with the application of ascorbic acid, while the use of glycine betaine the $\mathrm{K}$ content reduced by $4.19 \%$ in 2016 and by $2.83 \%$ in 2017 . It was the treatments that had the lowest $\mathrm{K}$ content in soybean seedlings and had the poorest seed germination, regardless of whether it germinated at optimum or lower temperature. However, glycine betaine reduced not only $\mathrm{K}$ but also $\mathrm{Ca}$ content. The use of glycine betaine decreased in 2017 with a significant decrease in $\mathrm{Ca}$ content of $5.81 \%$. The results obtained can be explained by research conducted by Thor (2019). This author has concluded that $\mathrm{Ca}$ is an important factor for cell wall and membrane stability but also serves as a second messenger in many developmental and physiological processes, including the response of plants to biotic stress.

In this experiment, treatment by trait (TT) biplot was generated in order to explore the relationship among the studied traits and to visualize treatment influence on the observed traits. Percentage of total variation explained with first two principal components ranged from $76.87 \%$ to $79.89 \%$. The patterns in the biplot are accurate if all, or most of the studied information is explained with it (Yan, Frégeau-Reid, 2008). In this research both given biplots explained high percentage of the total variation. In TT biplot, correlation coefficient between any two traits is approximated by the cosine of the angle between their vectors, so that $r=\cos 180^{\circ}=-1, \cos 0^{\circ}=1$ and $\cos 90^{\circ}$ $=0$ (Yan, Rajcan, 2002). In the Figures 3 and 4 yield and seed germination are positively correlated. On the other hand, $\mathrm{K}, \mathrm{P}$ and lipid peroxidation are in negative association with them.

The correlation of yield and seed germination with $\mathrm{Ca}$, free proline and cold test varied depending on the year. The $\mathrm{N}$ content was weakly negatively correlated with yield and seed germination. On a TT biplot, the distance between the treatment and the biplot origin, which represents the vector length of a treatment, is measure of the treatment's peculiarity, i.e. how it differs from an "average" treatment (Yan, Frégeau-Reid, 2008). Treatments with longer vector that formed acute angles with desirable traits could be marked as better.

In a favourable year 2016, treatments with ascorbic acid, glycine betaine and salicylic acid increased yield, seed germination and free proline content. Treatment with water was similar to the control indicating its weak effect on observed traits. In an unfavourable 


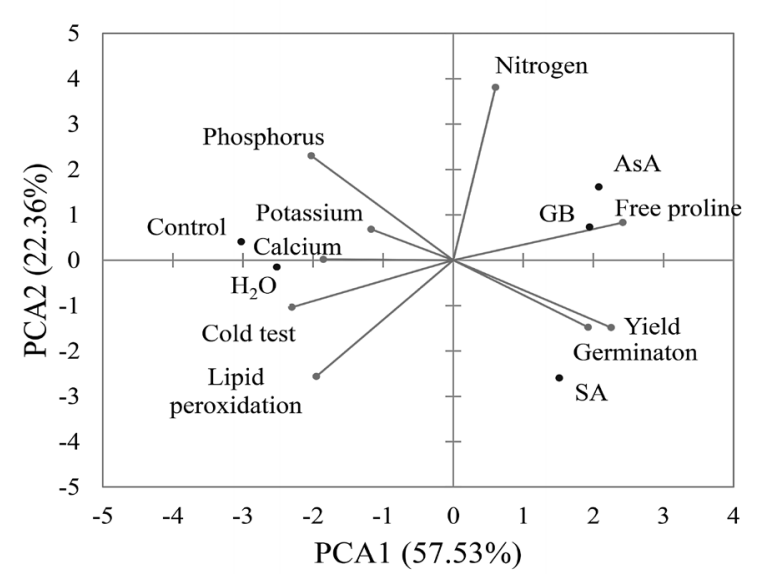

Figure 3. Treatment by trait (TT) biplot: solutions of ascorbic acid (AsA), glycine betaine (GB) and salicylic acid (SA) effect on yield and quality parameters of soybean in 2016

year 2017, yield and seed germination were increased with water, ascorbic acid and salicylic acid. It can be noted that ascorbic acid and salicylic acid increased these traits in both experimental years. Regarding cold test, only treatment with water managed to increase seed germination in 2017, while ascorbic acid, glycine betaine and salicylic acid decreased seed germination in both years of the experiment.

\section{Conclusions}

1. The foliar-applied solutions of ascorbic acid (AsA), glycine betaine (GB) and salicylic acid (SA) had a significant impact on soybean yield and seed germination.

2. The influence of the tested solutions on soybean seed yield was more pronounced, when the plants were better supplied with water, while the the solutions exerted a better effect on seed germination in the year with a significant water deficit.

3. In a favourable year 2016, treatments with ascorbic acid, glycine betaine and salicylic acid seed yield significantly increased by $6.21-9.67 \%$. However, in an unfavourable year 2017, the effect of water was significantly greater - it increased seed yield by $6.48 \%$, while the application of glycine betaine it reduced.

4. In a favourable year 2016, treatments with ascorbic and salicylic acids seed germination significantly increased by $7 \%$ and $8 \%$, respectively. In an unfavourable year 2017, also only ascorbic and salicylic acids seed germination significantly increased by $11 \%$ and $9 \%$, respectively.

5. When using cold test, only water treatment significantly increased seed germination in 2017; however, ascorbic acid and glycine betaine significantly reduced seed germination in both experimental years.

6 . It was found that the use of foliar-applied solutions of ascorbic acid, glycine betaine and salicylic acid had both a positive and a negative effect on the yield and seed germination, depending on the weather conditions of the growing season as well as on the temperature at which the seeds had been germinated.

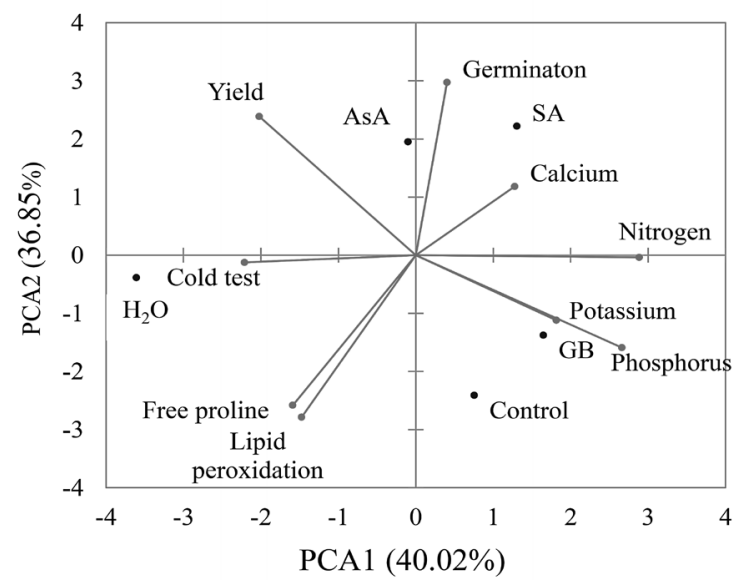

Figure 4. Treatment by trait (TT) biplot: solutions of ascorbic acid (AsA), glycine betaine (GB) and salicylic acid (SA) effect on yield and quality parameters of soybean in 2017

\section{Acknowledgements}

We wish to acknowledge the support of the Ministry of Education, Science and Technological Development of the Republic of Serbia, grant number: 451-03-68/2020-14/200032.

Received 22012020 Accepted 17062020

\section{References}

1. Alhasawi A., Castonguay Z., Appanna N. D., Auger C., Appanna V. D. 2015. Glycine metabolism and antioxidative defense mechanisms in Pseudomonas fluorescens. Microbiological Research, 171: 26-31. https://doi.org/10.1016/j.micres.2014.12.001

2. Aydin B., Nalbantoğlu B. 2011. Effects of cold and salicylic acid treatments on nitrate reductase activity in spinach leaves. Turkish Journal of Biology, 35: 443-448.

3. Bates L. S., Waldren R. P., Teare I. D. 1973. Rapid determination of free proline water stress studies. Plant and Soil, 39: 205-207.

https://doi.org/10.1007/BF00018060

4. Bremner J. M. 1996. Nitrogen-total. Sparks D. L. et al. (eds). Methods of soil analysis. Part 3. Chemical methods. Soil Science Society of America, p. 1085-1121. https://doi.org/10.2136/sssabookser5.3.c37

5. Cai F., Mei L. J., An X. L., Gao S., Tang L., Chen F. 2011. Lipid peroxidation and antioxidant responses during seed germination of Jatropha curcas. International Journal of Agricultural and Biological Engineering, 13 (1): 25-30.

6. Çavuşoğlu K., Bilir G. 2015. Effects of ascorbic acid on the seed germination, seedling growth and leaf anatomy of barley under salt stress. Journal of Agricultural and Biological Science, 10 (4): 124-129.

7. Çavuşoğlu K., Ergin H. G. 2015. Effects of humic acid pretreatment on some physiological and anatomical parameters of barley (Hordeum vulgare L.) exposed to salt stress. Bangladesh Journal of Botany, 44 (4): 591-598. https://doi.org/10.3329/bjb.v44i4.38595

8. Dalcin J. S., Nunes U. R., Roso R., Müller C. A., Backes F. A. A., Backes R. L., Mattioni N. M., Cargnelutti Filho A., dos Santos C. V., de Mendonça M. B. F., de Bastiani G. G., Barbieri G. F., Stefanello R., Ludwig E. J. 2019. Salicylic acid and its effect on physiological and photosynthetic parameters in soybean seedlings under water deficit. Journal of Agricultural Science, 11 (17): 280-286. https://doi.org/10.5539/jas.v11n17p280 
9. Đukić V., Miladinov Z., Dozet G., Cvijanović M., Tatić M., Miladinović J., Balešević-Tubić S. 2017. Pulsed electromagnetic field-a cultivation practice used to increase soybean seed germination and yield. ZemdirbysteAgriculture, 104 (4): 345-352. https://doi.org/10.13080/z-a.2017.104.044

10. Gallardo K., Job C., Groot S. P. C., Puype M., Demol H., Vandekerckhove J., Job D. 2001. Proteomic analysis of Arabidopsis seed germination and priming. Plant Physiology, 126: 835-848.

https://doi.org/10.1104/pp.126.2.835

11. Hampton J. G., TeKrony D. M. (eds). 1995. Handbook of vigour test methods ( $3^{\text {rd }}$ ed.). International Seed Testing Association Vigour Test Committee. Zurich, Switzerland.

12. Hasanah Y., Mawarni L., Irmansyah T. 2017. Production and physiological characters of soybean under drought stress with foliar application of exogenous antioxidant. Proceedings of the conference Future Agriculture: Socioecological Transitions and Bio-cultural Shifts, 9: 20-22.

13. Horváth E., Brunner S., Bela K., Papdi C., Szabados L., Tari I., Csiszár J. 2015. Exogenous salicylic acid-triggered changes in the glutathione transferases and peroxidases are key factors in the successful salt stress acclimation of Arabidopsis thaliana. Functional Plant Biology, 42 (12): $1129-1140$. https://doi.org/10.1071/FP15119

14. Huang X., Zhang X., Gong Z., Yang S., Shi Y. 2017. $\mathrm{ABI}_{4}$ represses the expression of type-A ARRs to inhibit seed germination in Arabidopsis. The Plant Journal, 89 (2): 354-365. https://doi.org/10.1111/tpj.13389

15. ISTA. 2008. International Seed Testing Association Seed health testing. International rules for seed testing. Bassersdorf, Switzerland.

16. Jayakannan M., Bose J., Babourina O., Rengel Z., Shabala S. 2015. Salicylic acid in plant salinity stress signaling and tolerance. Plant Growth Regulators, 76 (1): 25-40. https://doi.org/10.1007/s10725-015-0028-Z

17. Kuchlan P., Kuchlan M. K., Husain S. M. 2017. Effect of foliar application of growth activator, promoter and antioxidant on seed quality of soybean. Legume Research, 40 (2): 313-318.

https://doi.org/10.18805/lr.v0iOF.11302

18. Kumar V., Khare T. 2015. Individual and additive effects of $\mathrm{Na}^{+}$and $\mathrm{Cl}^{-}$ions on rice under salinity stress. Archives of Agronomy and Soil Science, 61 (3): 381-395. https://doi.org/10.1080/03650340.2014.936400

19. Kuźniar P., Szpunar-Krok E., Findura P., Buczek J., Bobrecka-Jamro D. 2016. Physical and chemical properties of soybean seeds determine their susceptibility to mechanical damage. Zemdirbyste-Agriculture, 103 (2): 183-192.

https://doi.org/10.13080/z-a.2016.103.024

20. Mandić V. B. Z., Krnjaja V., Simic A., Ruzic-Muslic D., Dragicevic V., Petricevic V. 2017. The rainfall use efficiency and soybean grain yield under rainfed conditions in Vojvodina. Biotechnology in Animal Husbandry, 33 (4): 475-486.

https://doi.org/10.2298/BAH1704475M

21. Miladinov Z., Balesevic-Tubic S., Djordjevic V., Djukic V., Ilic A., Cobanovic L. 2015. Optimal time of soybean seed priming and primer effect under salt stress conditions. Journal of Agricultural Sciences, 60 (2): 109-117 (in Serbian). https://doi.org/10.2298/JAS1502109M

22. Miladinov Z., Maksimovic I., Balesevic Tubic S., Djukic V., Canak P., Miladinovic J., Djordjevic V. 2020. Priming seed mitigates the effects of saline stress in soybean seedlings. Legume Research, 43 (2): 263-267. https://doi.org/10.18805/LR-469

23. Munger P., Bleiholder H., Hack H., Hess M., Stauss R., van der Bloom T., Weber E. 1997. Phenological growth stages of the soybean plant (Glycine max L. Merr.): condification and description according to the $\mathrm{BBCH}$ scale. Journal of Agronomy and Crop Science, 179 (4): 209-217. https://doi.org/10.1111/j.1439-037X.1997.tb00519.x
24. Naneswara D. M. 2016. Effect of antioxidants as foliar application on growth, seed yield and quality in soybean (Glycine $\max$ L. Merrill). M.Sc thesis. University of Agricultural Sciences, Bangalore, India, 88 p. https:// krishikosh.egranth.ac.in/handle/1/5810032537

25. Placer Z. A., Cushman L. L., Johnson B. C. 1966. Estimation of product of lipid peroxidation (malonyl dialdehyde) in biochemical systems. Analytical Biochemistry, 16 (2): 359-364.

https://doi.org/10.1016/0003-2697(66)90167-9

26. Plank C. O. 1992. Plant analysis reference procedures for the southern region of the United States. Southern Cooperative Series Bulletin, 68 p. http://www.ncagr.gov/ agronomi/pdffiles/sera368.pdf

27. Sadak M. S. 2015. Impact of foliar application of ascorbic acid and $\alpha$-tocopherol on antioxidant activity and some biochemical aspects of flax cultivars under salinity stress. Acta Biológica Colombiana, 20 (2): 209-222. https://doi.org/10.15446/abc.v20n2.43868

28. Shao R. X., Xin L. F., Guo J. M., H. F. Zheng., Mao J., Han X. P., Jia L., Jia S. J., Du C. G., Song R., Yang Q. H., Elmore R. W. 2018. Salicylic acid-induced photosynthetic adaptability of Zea mays L. to polyethylene glycolsimulated water deficit is associated with nitric oxide signaling. Photosynthetica, 56 (4): 1370-1377. https://doi.org/10.1007/s11099-018-0850-4

29. Shu K., Zhang H. W., Wang S. F., Chen M. L., Wu Y. R., Tang S., Liu C., Feng Y., Cao X., Xie Q. 2013. ABI4 regulates primary seed dormancy by regulating the biogenesis of abscisic acid and gibberellins in Arabidopsis. PLoS Genetics, 9 (6): 1003577. https://doi.org/10.1371/journal.pgen.1003577

30. Tan-Wilson A. L., Wilson K. A. 2012. Mobilization of seed protein reserves. Physiologia Plantarum, 145 (1): 140-153. https://doi.org/10.1111/j.1399-3054.2011.01535.x

31. Tarun K., Samaiya R. K., Yogendra S., Dwivedi S. K., Meena K. C. 2016. Effect of foliar application of plant growth retardants on growth, yield and yield attributing parameters of soybean (Glycine max L.). International Journal of Agriculture Sciences, 8 (50): 2158-2162.

32. Teixeira W. F., Fagan E. B., Soares L. H., Umburanas R. C., Reichardt K., Dourado-Neto D. 2017. Foliar and seed application of amino acids affects the antioxidant metabolism of the soybean crop. Frontiers in Plant Science, 8: 327.

https://doi.org/10.3389/fpls.2017.00327

33. Thor K. 2019. Calcium - nutrient and messenger. Frontiers in Plant Science, 10: 440. https://doi.org/10.3389/fpls.2019.00440

34. Valko M., Izakovic M., Mazur M., Rhodes C. J., Telser J. 2004. Role of oxygen radicals in DNA damage and cancer incidence. Molecular and Cellular Biochemistry, $266(1-2): 3756$.

https://doi.org/10.1023/B:MCBI.0000049134.69131.89

35. Vujakovic M., Balesevic-Tubic S., Jovicic D., TaskiAjdukovic K., Petrovic G., Nikolic Z., Djordjevic V. 2011. Viability of soybean seed produced under different agro-meteorogical condition in Vojvodina. Genetika, 43 (3): 625-638. https://doi.org/10.2298/GENSR1103625V

36. WRB. 2014. World reference base for soil resources. World Soil Resources Reports 106, FAO, 192 p.

37. Yan W., Frégeau-Reid J. 2008. Breeding line selection based on multiple traits. Crop Science, 48 (2): 417-423. https://doi.org/10.2135/cropsci2007.05.0254

38. Yan W., Rajcan I. 2002. Biplot analysis of test sites and trait relations of soybean in Ontario. Crop Science, 42 (1): 11-20.

https://doi.org/10.2135/cropsci2002.1100 
ISSN 1392-3196 / e-ISSN 2335-8947

Zemdirbyste-Agriculture, vol. 107, No. 4 (2020), p. 337-344

DOI 10.13080/z-a.2020.107.043

\title{
Askorbo rūgšties, glicino betaino ir salicilo rūgšties tirpalų, purkštuc per lapus, įtaka sojų sẻklų daigumui ir derliui Pietryčių Europos sąlygomis
}

\author{
Z. Miladinov ${ }^{1}$, S. Balesevic Tubic ${ }^{1}$, J. Crnobarac ${ }^{2}$, J. Miladinovic ${ }^{1}$, P. Canak ${ }^{1}$, V. Djukic ${ }^{1}$, \\ K. Petrovic ${ }^{1}$
}

${ }^{1}$ Novi Sad lauko augalų ir daržovių institutas, Serbija

${ }^{2}$ Novi Sad universitetas, Serbija

\section{Santrauka}

Tyrimo tikslas - nustatyti purkštų per lapus askorbo rūgšties, glicino betaino bei salicilo rūgšties tirpalų ir vandens ịtaką veislès 'Sava' gauruotosios sojos (Glycine hispida (Moench) Maxim.) sėklų daigumui ir derliui, taip pat šių tirpalų įtaką N, P, K bei Ca koncentracijai sojų sẻklose, ir įvertinti sojų daigų lipidų peroksidacijos intensyvumą bei laisvojo prolino kiekį. Tirtais tirpalais augalai buvo purkšti du kartus: pirmą kartą - žydejjimo (6) tarpsniu, pražydus pirmiesiems pavieniams žiedams, ir antrą kartą - grūdų formavimosi (7) tarpsniu, pirmajai ankštarai pasiekus 15-20 mm aukštị.

Tirpalų purškimas per lapus buvo reikšmingas $(p<0,05)$ sojų sėklų daigumui ir derliui abiem tyrimo metais. Palankaus klimato (2016) metais purškimas askorbo rūgšties, glicino betaino ir salicilo rūgšties tirpalais reikšmingai -6,21-9,67 \% - padidino sèklų derlių. Tačiau nepalankiais 2017 metais tirpalų poveikis buvo reikšmingai didesnis: purškiant vandeniu, sẻklų derlius padidejo 6,48 \%, o purškimas glicino betaino tirpalu jų derlių netgi sumažino. Palankaus klimato 2016 metais purškimas askorbo ir salicilo rūgščių tirpalais sėklų daigumą padidino reikšmingai - 7 ir $8 \%$. Nepalankiais 2017 metais sėklų daigumą reikšmingai padidino tik purškimas askorbo ir salicilo rūgščių tirpalais - 11 ir $9 \%$. Tačiau taikant šalčio testą, kai séklos 7 dienas buvo veiktos žema $\left(10^{\circ} \mathrm{C}\right)$ temperatūra, po to 4 dienas laikytos optimaliomis daigumo sąlygomis, askorbo rūgšties ir glicino betaino tirpalai sẻklų daigumą sumažino abiem tyrimo metais.

Reikia toliau ieškoti būdų, kaip padidinti sojų sėklų daigumą nepastovaus Serbijos klimato sąlygomis.

Reikšminiai žodžiai: askorbo rūgštis, daigumas, derlius, glicino betainas, salicilo rūgštis. 